is responsible for the environmental crisis, and the desire to dominate and lack of trust brought about the nuclear crisis (pp. 73-5). By the same token, there are also practical socio-political reasons behind what appear to be "religious" conflicts: hence the Israeli-Palestinian conflict pertains to usurpation and annexation of land, the Hindu-Muslim conflict in Kashmir is about occupation and territory, the Sinhalese conflict is linked to political rights and independence (pp. 58-9). Such analyses give an insight into the complexity and organic inter-relationship between the spiritual and the empirical rarely appreciated in discourses on socio-political affairs - a rich theme in itself yet one that would have been beyond the scope of the book, although the author's struggle to explore their dynamism and tension can be readily discerned in these pages.

Dr Chandra here is critical of hegemony and the elite who abused their position for their own gains, yet he does not dismiss their role altogether. The religious elite especially, has an important role to shape public opinion, but for that, "the influential stratum of society should acquire in-depth knowledge and understanding of not only the similarities and differences among the various religions, but also their underlying values and principles" (p. 62). At the popular level, all elements of society have to be mobilised towards this task, involving the state, civil society, educational institutions and the family. The latter especially, must continue their role as the means "through which values such as respect for cultural and religious diversity and the accommodation of the other [are] transmitted" (p. 88). The primary role of the state would be to create an atmosphere that will allow good values to flourish (p. 41). Indeed, the state itself, like the model exemplified by the Medina Charter, should be one based on shared values (p. 39).

The book hints at many promising themes and issues that appear as call-to-action. Yet to fully empathise with the author's intent, it is crucial to appreciate that his discourse is ultimately a spiritual one that demands patient and sustained struggle, both in society and within oneself.

\title{
Mohamed Ajmal Abdul Razak (ed.), Islam Hadhari: Bridging Tradition and Modernity
}

(Kuala Lumpur: International Institute of Islamic Thought and Civilization (ISTAC), 2009), viii+332 pp. ISBN: 978-983-9379-50-1 (hardback).

Norhayati Mustapha International Institute of Advanced Islamic Studies (IAIS) Malaysia

As a manner of introduction, the editor of the book under review gives the background to Islam Hadhari or Civilisational Islam, essentially a comprehensive 
blueprint for progress postulated by the then Prime Minister of Malaysia, Dato' Seri (now Tun) Abdullah Ahmad Badawi in the 2004 National Front Manifesto.

In "Civilizational Dialogue and the Islamic World", Seyyed Hossein Nasr traces the Greek, Sanskrit, and Latin Christian origins of the word 'civilisation'. He speaks of the "Presiding Idea", or "heavenly-given dispensation" that underlies all traditional civilisations, and attributes the decline of Islamic civilisation from the eighteenth century onward partly to colonisation and partly to the (erroneous) efforts of the Muslims themselves to uncritically emulate the West. Islamic civilisation, he concludes, is still best suited for inter-civilisational dialogue, occupying as it does the globe's "middle belt".

In his essay "Islam Hadhari from a Sharī'ah Perspective", Mohammad Hashim Kamali elaborates on each of the ten principles, interspersing his work with references to the Qur'ān and Sunnah. He regards the ten principles as open themes for the most part, on which to develop common perspectives and understanding; and views Islam Hadhari as a means to advance common interests of Malaysians of all faiths.

Next, in "New Approaches to Sharī'ah: Appreciating Islamic Values in Light of the Changes in Muslim Societies", Ahmad Kazemi Moussavi surveys the theories of four renowned scholars - Abū Isḥāq al-Shātịibī (legal methodology on the theory of maqāșid), Shāh Walī-Allāh of Delhi, Muhammad Iqbal (concept of human development as imbued in their legal approach), and Abdul Hamid Abu Sulayman (legal thought) - offering novel approaches whereby legal rules find a new characterisation suitable to the Muslim societies of their times.

In his exposition on "The Meaning of Civilization as Perceived by the Malays", Baharuddin Ahmad defines (and redefines) Malay culture, citing Western and Asian scholarly works, the cultural influence of India, links to Indonesia, the role of Islam and the legacy left behind by early Malay civilisation, which is largely manifest in the language rather than in buildings and structures. Islam Hadhari is perceived as a continuity of what has been practised by the Malays all along (faith in God, morality etc).

In "Islam Hadhari in the Context of the Traditional Malay-Islamic Discourse in the Malay World", Muhammad Uthman El-Muhammady studies each principle of Islam Hadhari by deeply interconnecting with the five universal necessities of ușül fiqh. He quotes frequently from Muslim scholars in the Malay world such as 'Abd al-Samad al-Falimbānī; and recounts narratives within the royal circles, interweaving his elaboration with poetic passages which extol virtues such as justice and trustworthiness.

"Islam Hadhari as a New Government Policy" by Mohd Kamal Hassan traces the historical background, the leadership's rationale behind Islam Hadhari, the responsibilities of the Malay people that it entails, and each of the ten principles 
of Islam Hadhari, explaining them with qur'ānic injunctions and illustrating its relevance to today's plural society. Above all, Mohd Kamal stresses the importance of implementation, consistency between theory and practice, and participation of the people.

In his essay on "Environmental Health and Welfare as an Important Aspect of Civilizational Islam", Osman Bakar contrasts the modern and the Islamic routes to environmental wisdom, rationalising why ecological consciousness is central to Islam, with insightful reference to works of renowned Muslim writers such as Seyyed Hossein Nasr, and even Christian and Jewish scholars. Fundamental ideas in Islamic ecological and environmental science are explored, underscoring the relevance of qur'ānic environmental wisdom to contemporary human life.

Cemil Akdoğan in his "Reappraisal of Islam's Impact on Modern Science" details how Muslims woke the Europeans from the 'slumber' of the Dark Ages, leading to their advancements in science and technology. He relates how Muslims established the tradition of normal science. He also explains how the achievements of the Muslim scholar al-Ghazāli anticipated the main ideas of Descartes, the father of modern Western philosophy, and also preceded Hume's work on causality, thereby reaffirming Islamic competence in the "rigorous pursuit and mastery of knowledge".

In "Islamic Economics in a Globalised World: Opportunities and Challenges for Muslims", Amer Al-Roubaie gives an in-depth account of Islamic economics by defining the problem before explaining the Islamic concept of development, its ethical foundations, economic institutions and administrations, ownership rights, and Islamic finance. He urges that Muslims need to re-engineer their own economic order and restructure the social equilibrium, adding that the revival of Muslim civilisation depends on the capabilities of the Muslims themselves in order to enhance their mastery of knowledge and to invest in modern technologies.

Sabri Osman's “Intercivilizational Exchange of Knowledge in the Intellectual Tradition of Islam: A Case Study on the Relationship between Islam's 'Ilm Tadbir al-Manzil and Ancient Greek's Oikonomia" takes the example of these two disciplines, which literally mean the 'Science of Household Management' in Islamic civilisation and Ancient Greece, respectively. Finding similarities between the two, he concludes that Islam is an open communicative civilisation, its process of critical selectivity being guided and administered by a unique perspective.

In "The Clash of Cultures: A Study of Muslim Literary Reaction to Western Domination”, Hassan A. El-Nagar studies two works of Muslim fiction, viz. Qindil Umm Hāshim (The Saint's Lamp) by Egyptian writer Yahyā Ḥaqqī and Ambiguous Adventures by Hamidu Kane, a Senegalese author. In Qindil Umm Hāshim, Haqqī emphasises the spiritual side of the East-West clash, which is considered by him a major component of the supposedly happy synthesis of religion and science in 
the Arab world, while Ambiguous Adventures powerfully depicts the 'evils' of the East-West encounter.

Amir H. Zekrgoo's "Trans-Cultural Nature of Islamic Art" defines Islamic art, recounts its genesis, distinguishes Persian from Byzantine art, and delves into Islamic art in Southeast Asia, referring also to works of art in other cultures such as Buddhism, Hinduism and Sikhism. His essay prolifically provides actual examples found throughout the world's sacred, religious and non-religious domains. He ultimately sees Islamic art as a form of traditional art where beauty and use go hand in hand, being two "inseparable aspects of perfection", as he has it.

Finally, in "Minorities in Muslim Societies: The Civilizational Context of Malaysian Pluralism" Muddathir Abdel-Rahim lays the religious and philosophical foundations of pluralism in the Islamic worldview, considers the legal status of non-Muslims in traditional Islamic states and societies, and relates the life of dhimmīs (non-Muslims, essentially 'People of the Book' but later broadened to include Zoroastrians and Hindus as well) in traditional Muslim societies; citing Malaysia as an outstanding example of tolerance and positive acceptance rooted in faith.

In conclusion, the book is an overview of Islamic Hadhari, explaining its relevance to modernity through various narratives of scholars within and without Malaysia. It touches the principles of faith in God and piety, rigorous pursuit and mastery of knowledge, a balanced and comprehensive economic development, cultural and moral integrity and safeguarding natural resources and the environment; allowing inferences to a just and trustworthy government, a free and independent people and a good quality of life. Admittedly, more could be said in this volume - particularly on the protection of the rights of women and minorities and strong defence capabilities - but as a 'primer' on Islam Hadhari and backed by links between the old and the new, the book is a useful reference and worthwhile read.

\section{Charles Tripp, A History of Iraq}

(Cambridge: Cambridge University Press, 2010, 3rd ed.), xxviii+357 pp.

ISBN: 978-0521702478. £17.00

\section{Christoph Marcinkowski International Institute of Advanced Islamic Studies} (IAIS) Malaysia

Charles Tripp's A History of Iraq is now in its third edition. Since 2000, when the first edition appeared, it has become a classic in Middle Eastern studies. The current edition has been updated to include the 2003 Anglo-American invasion, the fall and capture of Șaddām Ḥusayn, and the subsequent insurgency. Its author 